\title{
The ETHICS OF U.S. MONETARY POLICY IN RESPONSE TO THE FINANCIAL CRISIS OF 2007-2009
}

\author{
GEORGE BRAGUES*
}

IN THE NINETY-SIX YEARS since its founding, the U.S. Federal Reserve (Fed) has never been so daring, aggressive, or ground-breaking in its policymaking as it has in response to the current financial crisis brought upon by the collapse of the U.S. housing market. The Fed has slashed the interest rates under its control to practically zero, provided funds more freely and lavishly than ever before to a greater range of financial institutions and players, in addition to expanding swap lines with other central banks in order to inject liquidity into U.S. dollar markets world-wide. Most extraordinarily, it came to the rescue of various companies whose bankruptcy was deemed to pose a threat to the entire financial system.

Predictably, the Fed's policy response to the crisis has generated a torrent of commentary, much of it, given the recency of the events at issue, having thus far appeared in the media as opposed to the scholarly literature. While it is hard to quantify, the majority of observers have endorsed the Fed's actions, viewing these as the logical outcome of the central bank's lender of last resort function and the dictum that monetary conditions must be relaxed in proportion to expectations of slower economic activity (Wolf, 2008; Evans-Pritchard, 2008). According to this conventional wisdom, the Fed's policies have so far cushioned the U.S. and world economies from the potentially devastating impact of the financial tsunami and will eventually, especially if expansive fiscal policies are implemented, bring about recovery. Among the minority that have criticized the Fed, there are those who fault Ben Bernanke, the chairman of the Fed, for adopting a purely monetary diagnosis of the crisis and its cure, thereby marginalizing the Keynesian insight that, under dire economic conditions, fiscal policy is the only effective

${ }^{*}$ George Bragues (george.bragues@guelphhumber.ca) is the Program Head of Business at the University of Guelph-Humber in Toronto, Canada.

Cite This ARTiCle As: George Bragues, "The Ethics of U.S. Monetary Policy in Response to the Financial Crisis of 2007-2009," Libertarian Papers 1, 31 (2009). ONLINE AT: libertarianpapers.org. THIS ARTICLE IS subject to a Creative Commons Attribution 3.0 License (creativecommons.org/licenses). 
instrument at the government's disposal (Krugman, 2009). Others have argued that Bernanke misconstrued the turmoil in the financial system as a liquidity squeeze, instead of recognizing the lack of trust between counterparties in the financial markets as a major problem (Schwartz, 2008; Taylor 2009).

This debate has almost entirely been oriented around the question: will the Fed's strategy work? In evaluating its decisions, the Fed is assumed to be chiefly dealing with a technical problem, in which the issue is about choosing the means that will actually realize a given end - the latter, in this instance, being the Fed's legislatively defined objective of price stability combined with economic growth. What has received far too little attention, at least explicitly, is whether Bernanke's Fed is embarked on an ethically sound course. Here, the question is not simply the efficacy of the means in attaining the end, but also whether the means are permissible and whether the end ought to be chosen.

This paper aims to partially fill this gap by focusing on the Fed's response to the ongoing financial crisis. To minimize the subjectivity to which moral evaluations are susceptible, we approach the topic from a variety of well-established and time-honored moral-philosophic perspectives. If a consensus, or a strong majority, can be reached from differing philosophic assumptions and starting points, then the resulting judgment attains a sufficient measure of objectivity to be legitimately compelling to all neutral observers. For this purpose, we apply Aristotelian virtue theory, Lockean natural rights, Kantian deontology, and utilitarianism. On the argument that a marked rise in the inflation rate is the most probable outcome of the Fed's recent money production, we contend that none of the four moral teachings, though utilitarianism comes closest, support the central bank's policies. With all our selected moral philosophies opposed to the Fed's efforts, we maintain that it is going down an immoral path.

\section{The Fed's Policy Response}

The crisis can be said to have begun precisely on August 9, 2007. On that day, the French bank BNP Paribas suspended redemptions on three of its funds because it had become impossible to fairly price the U.S. sub-prime mortgages securities in its portfolio (BNP Paribas, 2007). The market for these securities having suddenly become illiquid, it became evident to traders and investors that buyers were nowhere going to be found except well below recently prevailing prices and that, therefore, the balance sheets of the myriad of financial institutions holding these instruments had materially weakened. 
As this made it riskier for these institutions to lend to each other, the rates for doing so immediately shot up.

This was evidenced in the so-called TED spread measuring the difference between the three month Eurodollar futures contract and the three month U.S. Treasury bill rate. The Eurodollar contract reflects the three month London Interbank Offered Rate (LIBOR), representing the terms at which commercial banks lend to each other outside U.S. regulatory jurisdiction. Inasmuch as the TED spread relates this rate to the comparatively riskless alternative of lending money to the U.S. government through the purchase of Treasury bills, that figure captures the market's perception of the security of the private financial sector and its willingness to extend credit. In the three year period prior to August 2007, the TED spread generally ranged between 20 and 50 basis points $(1$ point $=.01 \%)$. But upon the announcement issued by BNP Paribas, the spread catapulted 28 basis points to 72 . In the ensuing week and a half, it reached 240 basis points, a level not seen since the 1987 stock market crash. It subsequently stabilized and remained within elevated ranges between 75 and 220 basis points until the crisis entered a more acute phase in the fall of 2008, when the TED spread leapt to an all-time high of 456 basis points in the aftermath of the bankruptcy of Lehman Brothers, a top tier investment bank (Figure 1). As the crisis began to recede in late 2008, the TED spread narrowed, falling below 50 basis points by the spring of 2009 .

Figure 1: TED Spread, 2006-2009

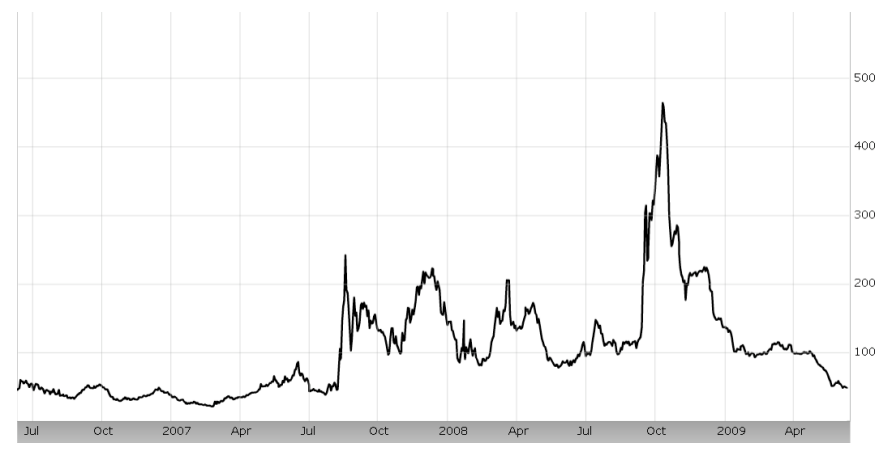

Source: Bloomberg

To understand the Fed's management of the crisis, one must consider the core ideas swaying its most powerful official. As a scholar of the Great Depression prior to becoming Fed Chairman, Bernanke is sympathetic to Irving Fisher's debt-deflation theory, which the latter used to explain what happened in the early 1930's (Bernanke 1983; Bernanke, 2007). According to Fisher (1933), when a debt-driven boom, such as that which took place in the 
2000s, comes to an end, the economy goes into a downward spiral, as people's attempts to escape debt gives rise to asset sales, which lowers prices, in turn raising the real value of people's debt, and thereby forcing more asset sales so that the entire destructive process starts again and repeats itself. This cycle could be stopped, Fisher thought, if the monetary authorities turned on the printing presses: "I would emphasize the important corollary, of the debtdeflation theory, that great depressions are curable and preventable through reflation and stabilisation" (p. 350).

Another well-known influence shaping Bernanke's understanding of the crisis is Milton Friedman's interpretation of the 1930s, written with Anna Schwartz as a chapter in A Monetary History of the United States (1963). Opposing the then dominant Keynesian view, which interpreted the Great Depression as a product of low aggregate demand, Friedman and Schwartz argued that the blame lay with the Fed for not providing adequate liquidity to the financial system in the early 1930's amid a series of bank runs and failures. In remarks he gave at an event celebrating Friedman's $90^{\text {th }}$ birthday, Bernanke took the opportunity of speaking on behalf of the Fed: "I would like to say to Milton and Anna: Regarding the Great Depression. You're right, we did it. We're very sorry. But thanks to you, we won't do it again" (Bernanke, 2002).

Guided by this intellectual framework, the Bernanke-led Fed has sought to quell the turmoil with a three-prong approach. The first has involved the use of the Fed's traditional monetary policy tools to influence the interest rate structure of the economy via its control of the Fed funds rate. The latter, the rate at which commercial banks reserve funds to each other, was initially cut by 50 basis points from $5.25 \%$ to $4.75 \%$. By December 2008, just fifteen months after its initial reduction, the Fed funds rate had been brought down to the $0-0.25 \%$ range, the first time ever that an effective zero interest rate policy had been implemented by an American central bank (Figure 2).

Figure 2: Federal Funds Rate, 2005-2009

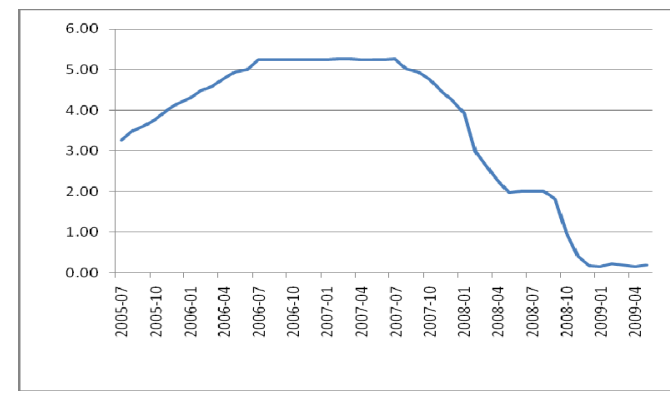

Source: St. Louis Fed 
The second prong of the Fed's policy towards the crisis has consisted in the provision of liquidity. This is straight out of the playbook famously elaborated by Walter Bagehot (1962) in Lombard Street. Bagehot's counsel was premised on the interdependence of individuals and firms within the credit system. When, as happens during a financial crisis, everyone demands liquidity simultaneously, the supply of it will quickly be depleted, jeopardizing the main storehouses of that liquidity, namely the banks. In this circumstance, as Bagehot put it:

\begin{abstract}
What is wanted and what is necessary to stop a panic is to diffuse the impression, that though money may be dear, still money is to be had. If people could be really convinced that they could have money if they wait a day or two, and that utter ruin is not coming, most likely they would cease to run in such a mad way for money. Either shut the Bank at once, and say it will not lend more than it commonly lends, or lend freely, boldly, and so that the public may feel you mean to go on lending [pp. 31-32].
\end{abstract}

The entity best positioned to "lend freely", Bagehot pointed out, is the holder of the ultimate reserves, the central bank. Bernanke's Fed has taken this advice with alacrity. Whereas before commercial banks had to pay a 100 basis point premium to the Federal funds rate to borrow at the discount window, this price was lowered to 25 . Loans were no longer extended merely on a short-term basis, but up to 90 days. An assortment of novel lending programs were set up, including the Term Securities Lending Facility by which the Fed lends to treasury securities dealers against illiquid instruments, as well as the Term Asset-Backed Loan Securities facility in which funds are issued against securities backed by credit card, student, auto, and business loans. Programs have also been established to support money-market funds and the commercial paper market (Bernanke, 2009a; Willardson, 2008).

As to the third prong of the Fed's policy response, this encompasses a broader set of actions designed to stabilize the financial structure and bolster the over-all functioning of credit markets. Under this heading comes the Fed's various endeavors to save and prop up specific financial institutions reckoned as being "too big to fail", including Bear Sterns, AIG, Citigroup, and Bank of America. In a bid to bring residential mortgage rates down, the Fed has committed itself to buying $\$ 200$ billion of the debt issued by Fannie Mae, Freddie Mac, and the Federal Home Loans Banks, in addition to $\$ 1.25$ trillion of mortgage-backed securities (Bernanke, 2009b \& Federal Reserve Press Release, 2009). For the first time since the 1960's, the Fed also announced that it will purchase up to $\$ 300$ billion of longer-term Treasury bonds (Whitman, 2009). 


\section{The Specter of Inflation}

In order to morally evaluate this set of policies, a general outline of the likely outcome needs first to be given. This will provide the basic picture from which the more specific applications demanded by our four chosen moral perspectives can be drawn. It must be acknowledged, however, that it is impossible to predict with certainty and precision what will happen, much less exactly when,as a consequence of particular government actions. Such is the multiplicity of causal forces operating in the social realm, each of these working in conflicting directions with varying levels of strength and magnitude, that it is beyond the human intellect's capacity to account for all the factors necessary to generate perfectly accurate forecasts. As such, we cannot simply look to history for recurrent patterns relevant to any given prediction problem, inductively infer causal principles, and then apply these to future events. Whatever generalizations we are able to derive from social phenomena, there are always differences between the facts compared, such that one can never discount the possibility that the patterns discerned reflect the operation of unobserved or complementary factors (Mill, 2002, pp. 57378).

For example, in trying to make sense of the crisis, commentators have been wont to invoke the example of Japan during the 1990s because, like the United States afterwards, it too underwent a real estate bubble that ended up causing grievous stresses in its financial system. And like the U.S. Fed, the Bank of Japan reacted by lowering interest rates to zero and injecting massive amounts of liquidity. Alongside these similarities, though, are significant differences in political culture, bank sector concentration, financial structure, the social distribution of debt, central bank traditions, not to mention the pace of the policy response. So while it is not entirely unhelpful to draw the analogy with Japan, it cannot form the basis of a rationally grounded assessment of the future. For that, we must engage in a logical deduction from economic principles by elucidating the key factors and holding everything else equal. Once this is completed, we can apply the results of the logical analysis to more fully understand specific historical cases. This may not render us oracular, but it will convey a probabilistic sense of the direction to which we are tending as a result of the Fed's actions.

When we consider how these have impacted the American central bank's balance sheet, it is clear that the most critical variable being affected is the money supply. Usually, a substantial portion of the Fed's assets consists of U.S. treasury securities. Owing to all of its activities throughout the crisis, however, the quality of the Fed's balance sheet has deteriorated. On the eve of the crisis, Treasury securities constituted $53 \%$ of the Fed's assets. As of February 2009, that proportion had been more than halved to $25 \%$, a good 
part of the difference being made up by all the assets acquired through the Fed's newly established facilities. Should economic conditions worsen and the Fed be forced to write down these assets, it may have to obtain an equity injection from the government which, if subsequently monetized, would augment the money supply. A more ominous spur to the production of money, though, comes from the sheer growth of the Fed's balance sheet. From August 2007 to June 2009, its assets have more than doubled from $\$ 902$ billion to $\$ 2.1$ trillion, the biggest increase since the $60 \%$ annual rise recorded between 1933 and 1934 (Federal Reserve Statistical, 2009; Willardson, 2008). Much of this growth came relatively later in the crisis towards the end of 2008 (Figure 3).

Figure 3: Total Factors Supplying Reserve Funds (proxy for Federal Reserve Assets) in billions of dollars, 2006-2009

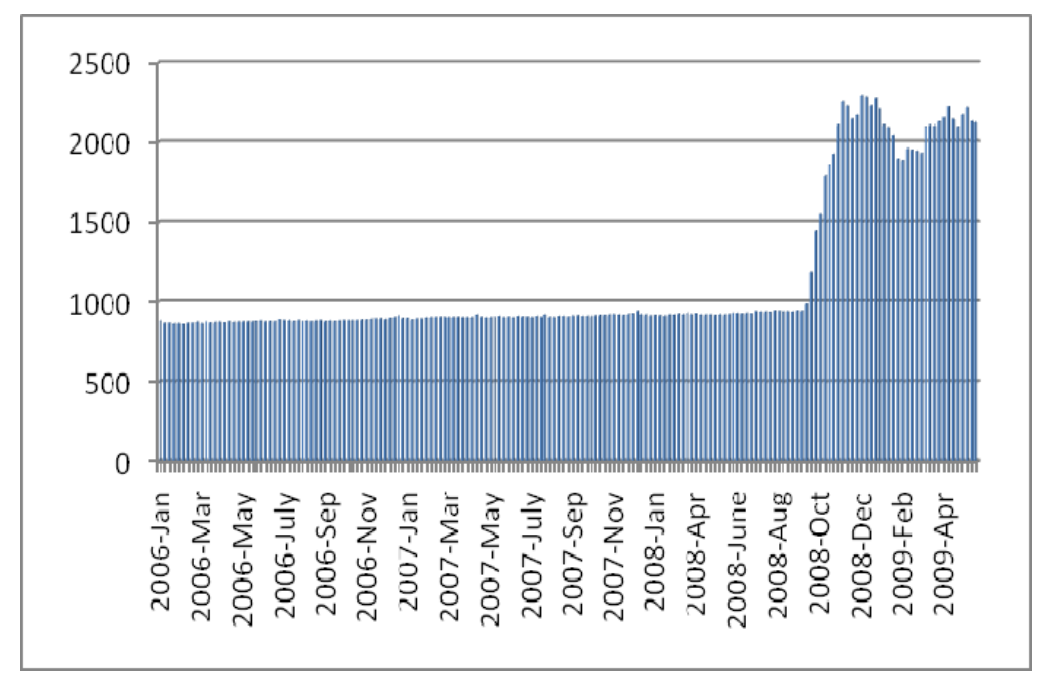

Source: U.S. Federal Reserve

Any increase on the left hand side of the balance sheet implies an equivalent one on the right hand side. Since the Fed operates with relatively little equity, this increase has occurred in the liabilities portion, mostly made up of currency circulating and commercial bank reserves held at the Fed. These two make up high-powered money, or what is more formally known as the monetary base and, as the graph below (Figure 4) dramatically lays bare, this quantity has recently shot up. 
Figure 4: Federal Reserve Monetary Base, 2006-2009

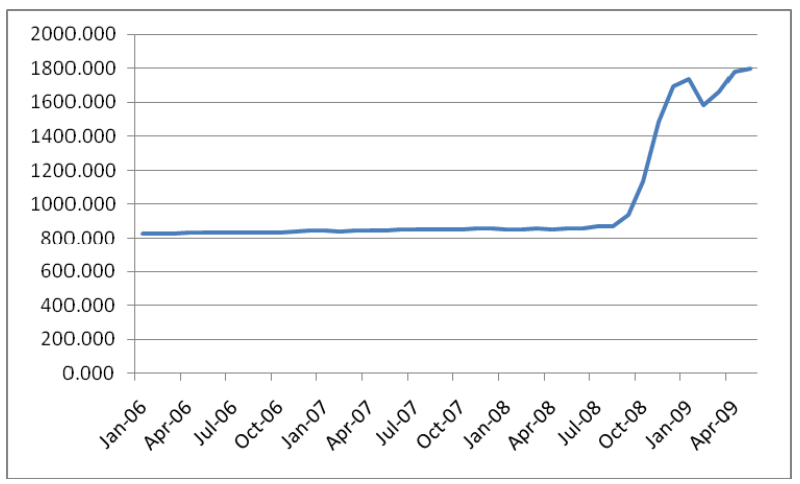

Source: St. Louis Fed

Shifts in the monetary base can generate disproportionately larger changes in the money supply insofar as the practice of fractional reserve banking allows banks to issue loans at a multiple to the amount of reserves they hold at the Fed. Thus far, given low borrower demand and the desire to shore up capital-asset ratios, banks have not taken full advantage of the Fed's expansion of its reserves. These have persisted at very high levels (Figure 5). But once confidence in capital-asset ratios is restored, and lending opportunities emerge with a reviving economy, the money supply will explode -- unless, that is, the Fed immediately acts to drain liquidity out of the financial system.

Figure 5: Reserve Balances with Federal Reserve Banks

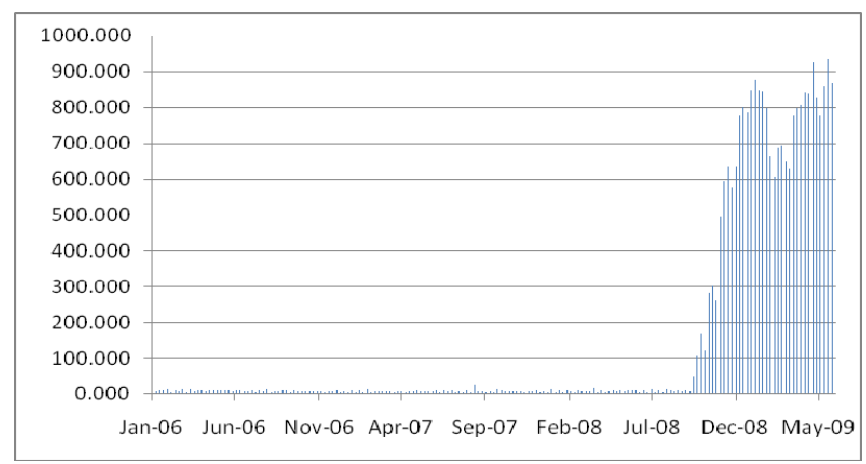

Source: St. Louis Fed

Bernanke (2009c) has offered assurances that this can be readily accomplished. Politically, however, this will be extremely difficult for the Fed to engineer, as we can expect that the cry will immediately go up, particularly 
from Wall Street and Congress, that the central bank is nipping economic recovery in the bud. The last time the Fed dramatically eased monetary policy in response to an economic downturn in 2001-2002, it waited several years before tightening and then did so gradually, in the process fueling the real estate bubble whose inevitable popping has led to our current difficulties. Worrisome, too, is the implication of Peter Bernholz's (2003, pp. 69-74) conclusion that serious bouts of inflation are ultimately rooted in large public sector budget deficits that politicians feel compelled to monetize. Under the plans laid out by the newly installed Obama administration, the US budget deficit is set to reach the highest levels (as a percentage of GDP) since World War II.

Given this set of circumstances, the logical sequence of events is pretty clear. Similar to any good, money has an exchange value predicated on supply and demand. The demand for money is equal to the level of cash balances that individuals wish to hold as well as their willingness to sell goods for cash. Supply, in turn, is the sum of the money stock and people's desire to retain a store of goods (Rothbard, 2001, pp. 712-15). Increased demand will raise the exchange value of money, and hence increase its purchase power so as to be deflationary. Increased supply will do the opposite, lowering the exchange value and thus reducing money's purchasing power so as to be inflationary. Since the growth in the money stock portended by the Fed's policies is so huge, we can legitimately surmise that any increase in demand that might occur will be overwhelmed by the upward shift in supply. Hence, we may logically deduce that the ultimate outcome of the Fed's response to the crisis will be significant inflation.

If we now turn to the historical record, we shall find this logical reasoning substantiated. That increases in the money supply give way to inflation can be seen very glaringly in the recent case of Zimbabwe (Hanke, 2008). Milton Friedman compiled statistics of money supply and consumer prices over varying time periods in the United States, United Kingdom, Germany, Japan, and Brazil, demonstrating a tight correlation (Friedman, 1994, pp. 196-202). Peter Bernholz (2003) analyzed inflationary episodes, both moderate and hyperinflationary, that occurred under paper money regimes and found that all of them were preceded by an increase in the money supply. Then there is the very recent history of gold prices, whose movements reflect inflationary expectations, which have strongly rallied since October 2008, approximately when the Fed's balance sheet started to balloon (Figure 6) 
Figure 6: Gold Price in US dollars, 2008-2009

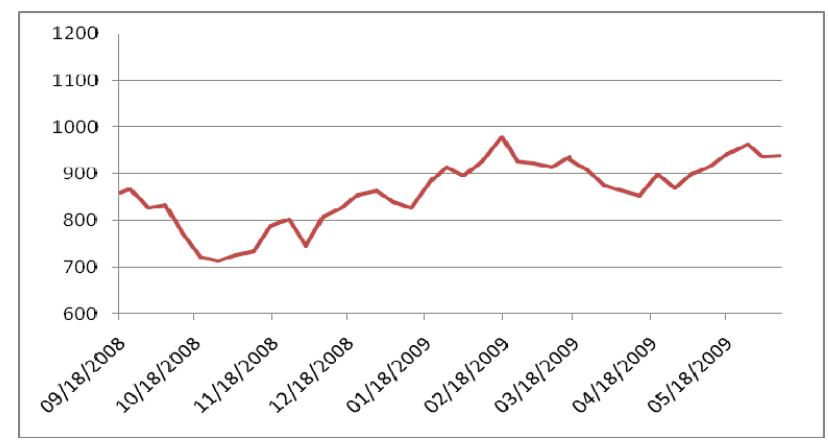

Source: Yahoo

\section{Applying the Moral Theories}

One difficulty faced by anyone exploring the moral dimensions of monetary policy is the paucity of reference material in the contemporary literature. Indeed, the issue has been systematically neglected long before our present financial difficulties arose. We must go as far back as the 15 th century to the late scholastics of the Salamanca school where we find a way of economic thinking that integrated such ethical concerns in its analysis (Chafuen, 2003, pp. 65-68). But afterwards came the separation of economics from ethics, which reached its culmination in the $20^{\text {th }}$ century with the positivist distinction between facts and values (Robbins, 1932, pp. 12735). With economics thus assigned to address the former, monetary policy has become the preserve of a technocratic clique using recondite models and equations to explore and optimize the relationships between various macroeconomic aggregates. In doing so, they are actually applying a form of utilitarianism, according to which policies are judged solely by their likelihood to maximize social welfare understood in terms of a time series of price and output data. Not being fully conscious, though, of the moral implications of their inquiries and counsel, this utilitarian approach ends up being taken for granted. Among those engaged in moral philosophy who might be expected to scrutinize these assumptions, in political theory and business ethics for example, one comes across an intellectual desert on the normative aspects of monetary policy. Jorg Guido Hulsmann (2008) rightly observes that "we face a wide gap" (p. 2) when it comes to the contemporary literature on the ethics of money production.

But the main obstacle to the moral evaluation of the Fed's efforts has to do with this question: which ethical standards should we apply? To many, economists in particular, the choice seems ultimately subjective. And if that is 
the case, the only reason why a person might agree with a particular moral analysis of the Fed's management of the crisis is that they happen to sympathize with the writer's ethical assumptions or they are moved by the latter's rhetorical skills. There would be nothing to rationally compel a person to assent to any moral conclusions in the way that one is forced to concede that two plus two equals four or that the earth is closer to the sun than Jupiter.

The overriding factor explaining such doubts about the objectivity of moral philosophy is that its practitioners have not succeeded in producing agreement as mathematicians and natural scientists have done in their respective disciplines. Yet this means that if unanimity, or a strong majority, could be generated out of the resources of moral philosophy, the results would have to be accorded the same authority as established propositions in mathematics and science. As a general matter, this would be a supremely tough task and it is this difficulty that lends so much power to the subjectivist claim. Yet consensus is possible on particular issues. Consult various moral traditions whether it is right to kill an innocent human being or steal an individual's personal property and one would surely come away from the exercise identifying wide agreement. Hence, the question becomes: is there a moral consensus to be found concerning the eruption of inflation which the Fed's policies both logically and empirically point to?

To strengthen the validity of any such consensus, we have chosen four moral theories, each varying in their core assumptions. Some focus on the individual, while others emphasize society. Perspectives that isolate actions as the unit of ethical analysis are opposed to those that single out a person's character. Our selection poses duties against rights, utility against individual autonomy, appeals to nature and everyday opinion versus convention and a priori reasoning. So that a spurious correlation does not arise from points of view biased by the zeitgeist of our time, or of any particular period for that matter, we have made sure to include ethical teachings originally developed in different eras and to elucidate their principles as their philosophic architects understood them. Satisfying these criteria are: Aristotle's virtue theory, John Locke's philosophy of natural rights, Immanuel Kant's deontology, and the utilitarianism of Jeremy Bentham.

\section{Aristotelian Virtue Theory}

Aristotle maintained that ethics was about acting in ways that further our purpose as human beings. This telos, the Greek philosopher argued, could be gleaned from the logic of our choices, all of which ultimately point to our overriding and ineluctable longing for personal happiness, for a fulfillment 
both profound and complete. It follows that morality consists in those rules of conduct that optimally satisfies this longing. For Aristotle, happiness is not equivalent to a subjective feeling of contentment. The summum bonnum, as the medieval philosophers called it, is an objective reality manifest in a way of life that fully actualizes our uniquely human capacities. What distinguishes human beings from the rest of the animal kingdom is our reason by which we are able to comprehend theoretical and practical truths as well as manage our passions. To perfect these abilities, according to Aristotle, we must cultivate a set of moral and intellectual virtues, habitual tendencies of action and thought that together form the model of a good character. Developing such a character, with a view to leading a flourishing existence, is the essence of Aristotelian ethics.

Among all the virtues discussed in Aristotle's Nicomachean Ethics, two are particularly germane to the issue of inflation. Let us begin with liberality, which involves the giving and receiving of money (Aristotle, 1985, 1119b201122a17). By giving and receiving, Aristotle does not simply refer to gifts, but also to the purchase and sale of goods and services. Reflecting his general thesis that virtue is a mean between two vices, Aristotle pictures liberality as standing roughly in the middle of a continuum, where illiberality is on one extreme and prodigality is on the other. Illiberality expresses itself either in the person who makes too few outlays or in someone seeking excess receipts, that is, either through stinginess or avarice, though certain individuals can manifest both simultaneously. The prodigal, by contrast, expends too many of his resources, while exercising relatively little care on preserving and augmenting his wealth.

Based on his analysis of everyday moral opinion, Aristotle argues that illiberality is the worse of the two extremes, particularly inasmuch as greed leads people into exploitive and high-risk occupations that offer proportionately little in return, harming their reputation by, for example, pimping, running a petty gambling operation, or providing high-interest loans to those with poor credit (i.e., loan sharks or payday loan providers). People that are merely stingy are not so objectionable since, whether out of a sense of fairness or fear, they refrain from the property of others. Still, as Aristotle sees it, they do not disseminate their resources in the community whereas at least the prodigal does. Where the prodigal goes wrong is in not taking care to avoid the exhaustion of their wealth, thereby undercutting their capacity to give virtuously in the future. Liberality avoids this by ensuring that outlays are kept in line with available means, while retaining the prodigal's focus on expending one's wealth rather than saving and acquiring more of it. The individual exemplifying liberality is thus nonchalant about money and, indeed, 
liable to getting shortchanged in transactions, being more anxious about not paying a fair price than the prospect of overpaying.

Inflation strikes at the heart of liberality by undermining the indifference to riches grounding that virtue. Aristotle notes that such indifference is more often found in those who have inherited their wealth as opposed to having acquired it on their own. The self-made know what it is like not to have money and, similar to poets, they become attached to what they have created. In Aristotle's time, when land ownership was the foundation of personal wealth, inflation would have had a relatively limited impact on people's attitudes towards wealth, since real estate tends to maintain its value amid a general rise in prices. But today, when so much of our wealth is held in the form of money and to claims on it flowing from bonds and stocks, inflation gnaws away at the purchasing power in which riches truly consist so that even the descendant of an affluent family comes to sense what it is like not to be well-off, while memories of this feeling are reinforced among those who have earned their fortune. The upshot is that inflation pulls individuals away from liberality towards acquisitiveness, as they are forced to devote more of their time and energy to coming up with ways of generating additional money income in order to maintain their purchasing power. Meanwhile, if we consider that the prodigal type is apt to borrow money to continue their lavish lifestyle, such behavior is encouraged insofar as inflation shrinks the real burden of debt.

A far more important virtue negatively impacted by the Fed's inflationary logic is justice. Aristotle divides this into commutative and distributive justice. The first regulates exchanges and states that each party must come away from any interaction having received as much as they gave (ibid., 1131b25-1132b20). The second takes personal qualities into account, stipulating that goods ought to be allocated in accord with merit (ibid., 1131a15-b24). Strictly speaking, distributive justice does not apply to a purely capitalist economy since it presupposes a specific individual or agency empowered to determine everyone's share of the wealth generated by society. Where free market principles prevail, these shares are impersonally set by the forces of supply and demand. Inflation, though, brings a particular entity into play, namely the government, whose injection of money into the economy redistributes wealth and incomes. Those on fixed incomes, and whose savings are invested in interest-bearing instruments, lose out relative to those in a position to have their wages indexed to inflation and whose holdings rest more on hard assets. This, in turn, changes people's spending patterns, as does the increase in cash balances brought about by the increased money supply, with the result that price ratios between goods and services are not simply preserved at higher nominal levels, but permanently affected 
(Rothbard, 2001, p. 852-53). Depending on what people have to buy, some will gain and others will suffer. This reallocation of resources takes place without any regard for merit.

It must also be acknowledged that additional money makes its way throughout the economy over time. The individuals who initially receive the new currency, finding themselves with higher than desired cash balances, utilize the excess to purchase goods and services from various parties, whose prices rise as a consequence of the increased demand. The sellers here will then deploy their cash balance surplus to buy goods and services from others and drive up the prices of their wares too, a process that goes on and on all the way through the intricate network that connects individuals and firms in the economy until the added funds have been fully put to work and prices have been generally bid up as high as the novel monetary conditions warrant (Mises, 1996, pp. 412-13). Clearly, one is better off at the earlier phases of this sequence, since that furnishes the opportunity of buying at prices that have not yet assimilated the injection of money. This situation is all the more advantageous to the extent that sellers take time to figure out that the additional demand for their goods is owing to the currency printing press instead of a shift in consumer preferences.

Now money, as Aristotle (1985) sees it, is that which enables us to conveniently equate the value of goods so that commercial transactions can satisfy the reciprocity demanded by commutative justice (1133a26-b26). In doing so, money represents demand, which is what ultimately renders different goods commensurable, but it performs this function by providing a common measure of value. Money, though, cannot play this role while its purchasing power is in flux. When this state of affairs prevails, commutative justice cannot exist. Buyers and sellers operate under divergent conceptions of what money is measuring. One must inevitably gain at the expense of the other. It is true that the advantaged party may not always be aware that they are the winner of a zero sum game, yet one cannot discount the possibility that a fair number will have grasped what is transpiring with the money supply better than their respective counterparties. Besides, the central bank is the real perpetrator here and Fed officials know exactly what they are doing.

\section{Lockean Natural Rights}

John Locke, the $17^{\text {th }}$ century British thinker, claimed that to understand the proper role of government, one must envision what it was like before political authority was established in human affairs. In other words, we must undertake an intellectual excursion back to the state of nature and spell out the progression of events that led to the institution of the state. Locke, of 
course, was not the first to adopt this method, as Thomas Hobbes had previously described the state of nature as a place in which no obligatory norms of justice existed and individuals were free to do anything they deemed necessary to promote their interests, with the outcome that life there was nasty, brutish, and short. Locke, by contrast, reckoned that social cooperation is possible in the state of nature and that its inhabitants are subject to universal moral principles discoverable by reason. These principles constitute the law of nature, which specifies that human beings are equal as well as free to do as they please so long as they do not violate other people's rights to life, liberty, and property (Locke, 1960, para. 6).

Of these rights, that of self-preservation is foundational, it being the precondition of our innate and overriding pursuit of happiness (Locke, 1975, p. 67). From the right of self-preservation, it follows that we have a right to liberty, since we would jeopardize our chances of survival were we to place ourselves under the absolute command of another person. As such, each of us is endowed with self-ownership, each is, "the absolute Lord of his own person" (Locke, 1960, para. 123). And from this property right we have over our selves, we acquire a similar right over external things.

Labor is what makes this last transition possible. In the beginning, Locke says, the earth and its resources belonged to all of humanity. But in applying their labor to a bit of the world, individuals mixed their selves with that bit, thereby diffusing their ownership of the latter onto the former (ibid., para. 27-29). This does not mean, Locke cautions, that people can acquire goods without limit. No one is permitted to holdings that spoil or go to waste in their possession, as that deprives other people of items that they could have otherwise used (ibid., para. 31). In a barter economy, this spoilage proviso was respected, if only because there were few incentives to amass a stock of goods for future exchange opportunities, when much of that stock was liable to decay.

The introduction of money, however, transformed matters by furnishing an object that could be accumulated without reducing the benefits others could draw from the world's resources. Money does not spoil. Precisely for this reason, it motivates individuals to be more productive with their property, since they can exchange the fruits of their labor for something durable that is always on hand and willingly accepted in trades for any good one may happen to desire whenever one desires it. This increased productivity expands the supply of goods available in the marketplace, leaving everyone better off then they would be if resources were communally owned, even those excluded the use of other people's resources by the right to property (ibid., para. 36-41). Though this economic co-operation emerged within the state of nature, the security of property rights was precarious there 
since it was left to each person to enforce them. As a self-serving bias was likely to affect individual judgments, and engender cycles of revenge, people eventually agreed to empower a referee. Thus, does government come into being to secure individual's natural rights to property and it continues to have that task as its chief purpose (ibid, para. 124).

The moral problem, then, that the Fed's recent policies run into from the Lockean standpoint is that an agency of the government is undermining property rights. Inflation takes away part of the value of people's money assets. It is governmentsanctioned theft. Against this conclusion, one might point out that we have consented to the government's policies through the election of representatives whom we have empowered to regulate property for the public interest. Locke, admittedly, provides the basis for such an argument and goes so far as to say that a majority decision by elected representatives counts as consent, since a unanimity requirement would incapacitate the government from acting (ibid., para. $96 \& 140$ ).

However, nobody that runs monetary policy in the United States, the Chairman of the Fed and its Board of Governors, is voted into office. The Fed, like other major central banks in the world, is specifically designed to have a measure of independence from the political process. Granted that the President, who appoints Fed officials, and the Senate, which confirms them, is elected, it is nevertheless the case that monetary policy is hardly ever a topic of debate in political campaigns. Nor can there truly be property rights if, at any time, a minimum of $50 \%$ plus one of the population could strip the minority of their possessions. This helps explain why Locke insists that the government's regulatory power is limited by the common good. But what kind of common good is it when, as happens with inflation, the person who is effectively "long" money (a saver or creditor) loses to the individual effectively "short" (a debtor or the holder of a large proportion of hard assets)? One would have to argue that the losses suffered by the longs are subsequently made up by an economic revival brought about by monetary easing. Still, the fact that people sell bonds, switch to foreign currencies, and look to gold to protect the value of their money assets whenever their inflationary expectations rise suggests they do not really agree with that reasoning.

\section{Kantian Deontology}

For both Aristotle and Locke, morality is predicated, albeit in different ways, on happiness -- whether in terms of its realization through the cultivation of a virtuous character or its pursuit as each of us sees fit in keeping with individual rights. To Immanuel Kant, however, what is morally 
vital is not the ultimate object of the human will, but the quality of that will. "There is no possibility", the $18^{\text {th }}$ century German philosopher declares, "of thinking of anything at all in the world, or even out of it, which can be regarded as good without qualification, except a good will" (Kant, 1981, p. 7). Doing the right thing for its own sake, rather than for some higher end, is the point of human existence. If nature had intended us to be happy, then our instincts would have more surely inclined us in that direction. Instead, we have been left with our reason to decipher the route to bliss and it is not up to the task given all the unpredictable contingencies along the way. What is more, putting the intellect at the service of our desires would contravene what defines us as human beings, to wit, our rationality and ability to transcend our natural inclinations. In the Kantian language, the prioritization of happiness would degrade us to a level of heteronomous, rather than autonomous, existence. Living up to the dignity of a rational being entails that we regulate our will in conformity with general and unconditional principles legislated by ourselves.

To this end, Kant presents the categorical imperative. According to this formula, any prospective course of action can be morally tested by posing two questions. First, can the act be willed as a universal law without contradiction? As an illustration, Kant considers an individual who needs to borrow money knowing full well that they cannot repay any loan extended to them. Of course, no one will advance credit to that person unless they promise to pay back the money. Should this person, then, intentionally make a false promise in order to obtain the loan? Answering this requires that we contemplate the implications of establishing the rule that anyone in financial straits can borrow money by insincerely pledging to repay the loan. Such a rule would, Kant observes, render promises meaningless, since no one would trust any assurances made to them if it were commonly acknowledged that people could lie whenever they deemed it in their interests. Insofar as a promise ceases to be a promise when its falsity is generally allowed, the act of deceitfully vowing repayment of a loan cannot be universalized without contradiction and is, therefore, immoral (ibid., p. 31).

The same conclusion can be derived from the second part of the categorical imperative: "Act in such a way that you treat humanity, whether in your own person or in the person of another, always at the same time as an end and never simply as a means" (ibid., p. 36). This maxim, a more concrete variation of the universalization requirement, enjoins us to treat other people as beings with their own goals and concerns, instead of objectifying them and using them for our own purposes, however exalted these might be. Calling to mind the same example as before, it would be wrong to issue a false promise when in need because doing so would not respect the borrower's concerns. 
The lender is reduced to an instrument serving the borrower's self-interest (ibid., p. 37).

Applying the categorical imperative to the Fed's management of the crisis, we would ask: can the act of injecting vast amounts of money into the financial system whenever the economy runs into difficulty be consistently rendered into a universal law? The answer is no. For one thing, money would lose its significance. When money is defined in terms of state monopoly issued notes, its value depends on the government's pledge that it will resist the many temptations to prolifically print it. To the extent that this promise is compromised, money becomes less and less a power of commanding goods for its possessor and more and more just another piece of paper. Not only that, the universal acknowledgement of the Fed's policies would be selfdefeating. Pumping up the quantity of money can only work on the assumption that individuals and firms are not onto what the Fed is doing. As soon as a company realizes that the extra demand for its product is owing to newly printed money, it will simply increase prices instead of raising production. Moreover, if workers expect that their wages will buy fewer goods as a result of the central bank's actions, they will immediately demand an increase in salary from their employers sufficient to compensate them for their prospective loss of purchasing power. This takes away any incentive that businesses might have had to augment investment due to a lower real wage bill having to be paid to inflation deluded employees. With output thus unaffected, all that transpires is a general rise in the price level, leaving those locked into fixed income arrangements and paper asset portfolios as losers.

Yet as Kant makes clear, an action can only be willed universally if one could conceivably consent to it wherever one might be situated (ibid., p. 32). No one would agree, surely, to be the holder of a five year certificate of deposit or a fixed annuity in an inflationary scenario. Given, too, what sequentially takes place upon the easing of monetary policy, no would want to be in the place of someone receiving the new money in the later stages of the liquidity injection. As if that were not bad enough, such individuals would be liable to being used as a means of furthering the interests of a more financially sophisticated party in exchanges. Nor should it be forgotten that if anyone is using individuals as a means, it is the Fed in deliberately attempting to diminish the purchasing power of those using its currency in order to advance its economic and political objectives.

\section{Utilitarianism}

Whereas the Kantian theory opposes both Aristotle and Locke in rejecting the idea of happiness as a morally decisive factor, utilitarianism tells 
us to return to that idea and systematically apply it. Though the elements of this teaching are to be found in Epicurus, Frances Hutcheson and David Hume, the original founder of utilitarianism, particularly as it is practiced today by its most avid exponents in the economics profession, is Jeremy Bentham, the 19th century English jurist and philosopher. John Stuart Mill (1972), who wrote after Bentham, is also widely regarded as a founder of utilitarianism, but he points to an objective conception of happiness, in famously stating that it is, "better to be a human being dissatisfied than a pig satisfied; better to be Socrates dissatisfied than a fool satisfied" (p. 10). This echoes the Aristotelian understanding of human flourishing, which we have already applied to the Fed's policies. To properly diversify our portfolio of moral philosophies, we will stick to Bentham's version of utilitarianism and invoke scholarly literature in keeping with it.

For Bentham (1948), conduct is to be judged by its consequences to the community. Actions are moral to the extent that they promote the community's utility, and immoral to the extent that these lessen it (p. 2). Utility is understood in subjective terms as the net balance of whatever a person finds to be pleasurable and painful, with the former obviously increasing that balance and the latter decreasing it. Rather than being conceived holistically as an entity in its own right, the community is nothing more than the name we give to a collection of individuals (ibid., p. 3). Accordingly, Bentham holds that the community's utility is the sum of individual utilities. It can be calculated by placing the number of those positively impacted by an action, weighted by the intensity and duration of their net pleasure, in the positive column and then doing the same in the negative column for those negatively affected by net pain. If the positive side of the ledger exceeds the negative, communal utility rises and the action passes the moral bar; and vice versa if the negative column outweighs the positive.

To run this sort of analysis vis-à-vis the Fed's management of the crisis might appear hopeless given the variety of consequences that can be envisioned, their different probabilities and potential permutations, not to mention the millions of people whose varying affective responses would have to be tabulated. With the Fed's actions, however, this calculation can be rendered tractable by focusing on its consequences to personal wealth. Everyday experience amply confirms that, as a general matter, individuals derive pleasure from riches and pain from poverty. Confirming this is the happiness studies literature, a growing area of scholarship that uses survey data to gauge the level and sources of people's subjective contentment (Frey \& Stutzer, 2002; Bruni \& Porta, 2005; Bruni \& Porta, 2007). According to its findings, individuals in wealthier countries report higher degrees of 
satisfaction with their lives than those in poorer countries. Likewise, within the same country, people in higher income brackets say they are happier than those lower down the income ladder (Frey, 2008, pp. 27-44).

Keeping this wealth-maximization criterion in mind, the Fed and its supporters basically make the following utilitarian argument in support of its flooding of liquidity: whenever a boom turns to bust, there is always the danger of deflation materializing once banks and financial markets lower the availability of credit to deal with losses incurred on investments made when the deal making grew feverish in the late phases of the expansion. This risk is all the greater now in light of the high leverage that developed in the financial system, the low level of personal savings, along with the widespread exposure to declining house prices. Only an aggressive increase in the quantity of money can counter the deflationary threat posed by the post-boom deleveraging process. While this strategy carries the risk of sparking inflation, the far worse outcome would be to let deflation take hold. For once this happens, a vicious spiral comes into play in which lower prices lead firms to lay off workers, who then lower their purchases of goods, which subsequently leads to further price cuts and employment losses (Posner, 2009).

At the same time, people form expectations of lower prices, causing them to delay any non-necessary purchases, while preventing bargain hunting behavior from halting the downtrend. With falling prices, the real burden of debts increase as well, further lowering consumption and giving rise to personal bankruptcies that leave creditors in the lurch. Without a dramatic expansion in the money supply, therefore, most will end up poorer, whether because of reduced employment income, the failure of their business, or losses on their equity and corporate bond portfolios. About the only people standing to gain are those that maintain their jobs and salaries and, moreover, have saved all their money in government treasury securities or a safe bank. If the Great Depression is any guide, this group is able to purchase goods at cheap prices (Johnson, 1983, p. 247).

Favoring this argument are the various studies establishing unemployment as a significant source of unhappiness (Winkelmann \& Winkelmann, 1998; Clark \& Oswald, 1994). One study uncovers that job loss has a psychological impact beyond what could be explained by the mere decline of income and that even those that remain employed are impacted in a recessionary period inasmuch as a rise in the unemployment rate fuels anxiety (Di Tella, MacCulloch, \& Oswald, 2003). To the extent that the utilitarian case above supposes a trade-off between unemployment and inflation, the happiness studies literature finds that people are more aggrieved by unemployment than inflation (Blanchflower, 2007). A 1\% rise in the 
unemployment has been determined to be equivalent to a $1.97 \%$ increase in inflation, almost twice the difference (Di Tella, MacCulloch, \& Oswald, 2001). Another calculation indicates that a 10 percentage point rise in the unemployment rate leaves the median individual as happy as someone at the $43^{\text {rd }}$ percentile in a scenario with no job loss, whereas a similar rise in the inflation rate puts the median individual at a point equivalent to the $45^{\text {th }}$ percentile in the base case (Di Tella \& MacCulloch, 2007).

Yet all these points assume that deflation is as harmful as the Fed believes and that inundating the economy with liquidity is an effective way to impede the damage. However, very easy monetary conditions slow down the necessary liquidation and restructuring of the malinvestments made during the upswing (Mises, 1996, p. 578). The inflation created by trying to delay this process with excess liquidity will eventually have to be curbed by a tightening of monetary policy. In this way, unemployment is simply put off into the future and the volatility of the economy is amplified. Granted, allowing the restructuring to unfold with a more limited easing may well bring about a steeper rise in the unemployment rate. But it will quicken the recovery, as evidenced by the downturn in 1920-1921, the last time the government took a laissez-faire approach towards the business cycle. It is not clear from the scholarship on happiness how the psychological impact of unemployment compares when we consider its duration versus its level. Common experience, at any rate, would suggest that intense short-term pains are easier to bear than more moderate, drawn out suffering. What is clear, though, is the lack of a connection between deflation and anemic economic conditions of the sort that produce high unemployment. As Atkeson and Kehoe (2004) show, based on analysis of 17 countries over more than a century, almost $90 \%$ of deflationary periods saw no depression. Historically, a $1 \%$ drop in inflation is correlated with a mere $0.08 \%$ decrease in real economic growth. Only during the Great Depression does deflation appear to be harmful, suggesting that the Fed is exaggerating the bearing of that episode to current events.

To this, one might counter that the distinction needs to be made between deflations that are productivity driven and those reflecting monetary factors. The first consists in an increase of the aggregate supply of goods, which the experience of the $19^{\text {th }}$ century demonstrates as benign (Selgin, 1997). The second, in accordance with the equation of exchange, leads to a decline in production, if the nominal quantity of money transacted on the purchase of goods and services is allowed to drop. That equation (MV=PQ) states that $\mathrm{M}$ (money supply) multiplied by the velocity of that money $\mathrm{V}$ (how often it circulates in exchanges) equals the general price level $(\mathrm{P})$ multiplied by output $(\mathrm{Q})$. Hence, any drop in velocity resulting from nervousness on the 
part of individuals and firms about spending must translate to a fall in PQ. Since wage rigidities in the labor market, particularly in the short-run, make it difficult for $\mathrm{P}$ to fall, the brunt of the adjustment will be felt in lower output Q. And that means lower incomes, higher unemployment, and all that these entail in terms of a reduction in over-all happiness. On utilitarian grounds, therefore, a compelling argument exists to increase the money supply to a level that neutralizes the drop in velocity. This way, the economy is prevented from collapsing while a reflation of the economy with cheap credit is avoided that would otherwise aggravate the malinvestments of the bubble period (cf. White, 2008, p. 94 citing Hayek). Yet it is hard to believe that the enormous volume of liquidity injected by the Bernanke Fed, described in Section II of this paper, is just enough to keep the monetary side of the exchange equation in balance. The Fed has clearly gone beyond that and sought to use lower interest rates to pump up previously booming sectors of the economy, such as real estate, as evidenced by its decision to purchase mortgage-backed securities.

\section{Conclusion}

The question raised by the Fed's unprecedented easing of monetary conditions in the wake of the financial crisis is not simply whether it will work, but whether it is right. Yet who is to say what is right? To overcome the skepticism inherent in this oft-asked question, we implement four disparate moral theories that have stood the test of time, namely Aristotle's virtue teaching, Locke's concept of property rights, Kant's deontology, and Bentham's utilitarianism. What each of these moral frameworks will have to say must depend, to one extent or another, on the projected impact and consequences of the Fed's tactics. These essentially amount to a significant increase in the money supply. Since the Fed is likely to find it politically difficult to reverse this flooding of liquidity once the economy gains some traction, the likely outcome is a substantial increase in the rate of inflation.

As such, none of the moral theories sanction the Fed's efforts: the Aristotelian view, because the Fed's actions threatens to undermine the virtues of liberality and justice; the Lockean, because property rights are violated; the Kantian, because the practice of copiously printing money to deal with economic difficulties cannot be logically conceptualized as a universal law and, moreover, it leaves individuals liable to being used as means to satisfy the ends of others; and the utilitarian, because the flooding of liquidity overstates the threat of deflation and understates that of delaying the necessary reorganization of the economy. The bottom line is that the Fed is proceeding on an immoral basis. 


\section{References}

Aristotle (1985). The Complete Works of Aristotle, Rev. Oxford. Trans. Jonathan Barnes (ed). Princeton: Princeton University

Atkeson, A \& Kehoe, P. (2004). Deflation and Depression: Is there an Important Link? AE A Papers and Proceedings. 94 (2), 99-103

Bagehot, W. (1962). Lombard Street: A Description of the Money Market. Homewood, Ill: R.D. Irwin.

Bentham, J. (1948). The Principles of Morals and Legislation. New York: Hafner Press

Bernanke, B. (1983). Non-Monetary Effects of the Financial Crisis in the Propagation of the Great Depression. American Economic Review, 73 (3), 257-76.

(2002). On Milton Friedman's Ninetieth Birthday. Remarks at the Conference to Honor Milton Friedman, University of Chicago. Chicago, Illinois. Retrieved March 9, 2009, from

http://www.federalreserve.gov/BOARDDOCS/SPEECHES/2002/2 $\underline{0021108 / \text { default.htm }}$

, (2007). The Financial Accelerator and the Credit Channel. Speech before the Te Credit Channel of Monetary Policy in the Twenty-first Century Conference, Federal Reserve Bank of Atlanta. Atlanta, Georgia. Retrieved March 9, 2009, from

http://www.federalreserve.gov/newsevents/speech/Bernanke2007061 $\underline{5 a . h t m}$

, (2009a, January 13). The Crisis and the Policy Response. Remarks at the Stamp Lecture, London School of Economics. London, England. Retrieved March 9, 2009, from

http://www.federalreserve.gov/newsevents/speech/bernanke2009011 $\underline{3 a \cdot h t m}$

(2009b, February 10). Federal Reserve programs to strengthen credit markets and the economy. Speech before the Committee on Financial Services, US House of Representatives. Washington, DC. Retrieved March 9, 2008, from:

http://www.federalreserve.gov/newsevents/testimony/bernanke20090 210a.htm

, (2009c, February 18). Federal Reserve Policies to Ease Credit and Their Implications for the Fed's Balance Sheet. Remarks at the National Press Club Luncheon. Washington, DC. Retrieved March 9, 2008 from: 
http://www.federalreserve.gov/newsevents/speech/bernanke2009021 $\underline{\text { a.htm }}$

Bernholz, P. (2003). Monetary Regimes and Inflation. Cheltenham, UK: Edward Elgar

Blanchflower, D. (2007). Is Unemployment More Costly than Inflation? NBER Working Paper No.W13505

BNP Paribas. (2007, August 9). BNP Paribas Investment Partners temporaly suspends the calculation of the Net Asset Value of the following funds: Parvest Dynamic ABS, BNP Paribas ABS EURIBOR and BNP Paribas ABS EONIA. Retrieved February 17, 2009, from http://www.bnpparibas.com/en/news/pressreleases.asp?Code $=$ LPOI75W9PV\&Key $=$ BNP $\% 20$ Paribas $\% 20$ Investment $\% 20$ Partners $\% 20$ tem poraly $\% 20$ suspends $\% 20$ the $\% 20$ calculation $\% 20$ of $\% 20$ the $\% 20$ Net $\% 20 \mathrm{~A}$ sset $\% 20$ Value $\% 20$ of $\% 20$ the $\% 20$ following $\% 20$ funds $\% 20: \% 20$ Parvest $\%$ 20Dynamic $\% 20 \mathrm{ABS}, \% 20 \mathrm{BNP} \% 20 \mathrm{Paribas} \% 20 \mathrm{ABS} \% 20 \mathrm{EURIBOR} \% 2$ 0and $\% 20 \mathrm{BNP} \% 20$ Paribas $\% 20 \mathrm{ABS} \% 20 \mathrm{EONIA}$

Bruni, L. \& Porta, P.L. (2005). Economics \& Happiness: Framing the Analysis. Oxford: Oxford University Press , (2007). Handbook on the Economics of Happiness. Cheltenham, UK: Edward Elgar

Chafuen, A. (2003). Faith and Liberty: The Economic Thought of the Late Scholastics. Lanham, MD: Lexington Books

Clarke, A. \& Oswald, A. (1994). Unhappiness and Unemployment. The Economic Journal, 104, 648-59

Di Tella, R., MacCulloch, R. \& Oswald, A. (2001). Preferences over Inflation and Unemployment: Evidence from Surveys of Happiness. American Economics Review, 99 (1), 335-41

(2003). The Macroeconomics of Happiness. The Review of Economics and Statistics, 85 (4), 809-27

Di Tella, Rafael \& MacCulloch, Robert (2007). Happiness, Contentment and Other Emotions for Central Banks. NBER Working Paper No. 13622

Evans-Pritchard, A. (2008, December 9). Deflation virus is moving the policy test beyond the 1930s extremes. The Daily Telegraph. Retrieved March 9, 2009, from 
http://www.telegraph.co.uk/finance/comment/ambroseevans_pritcha $\mathrm{rd} / 3629806 /$ Deflation-virus-is-moving-the-policy-test-beyond-the1930s-extremes.html

Federal Reserve Press Release (2009, March 18). FOMC Statement. Retrieved March 19, 2008 from

http://www.federalreserve.gov/newsevents/press/monetary/2009031 8a.htm

Federal Reserve Statistical Release (2009, June 4). Factors Affecting Reserve Balances. $\quad$ Retrieved June 10, 2009, from http://www.federalreserve.gov/releases/h41/20090604/

Fisher, I. (1933). The Debt-Deflation Theory of Depressions. Econometrica, 1 (4), 337-57. Retrieved March 9, 2009 from http://fraser.stlouisfed.org/docs/meltzer/fisdeb33.pdf

Frey, B. \& Stutzer, A. (2002). Happiness and Economics: How the Economy and Institutions Affect Well-Being. Princeton: Princeton University Press

Frey, B. (2008). Happiness: A Revolution in Economics. Cambridge: MIT Press

Friedman, M. \& Schwartz, A. (1963). A Monetary History of the United States 1867-1960. Princeton: Princeton University Press

Friedman, M. (1994). Money Miscbief: Episodes in Monetary History. San Diego: Harcourt Brace \& Company

Hanke, S. (2008). Zimbabwe: From Hyperinflation to Growth. CATO Institute, Development Policy Analysis, No. 6. Retrieved March 8, 2009, from http://www.cato.org/pubs/dpa/dpa6.pdf

Hulsmann, G. (2008). The Ethics of Money Production. Auburn: Mises Institute

Johnson, P. (1983). Modern Times. New York: Harper \& Row

Kant, I. (1981). Grounding for the Metaphysics of Morals. Indianapolis: Hackett Publishing Company

Krugman, P. (2009, January 5). Fighting Off Depression. The New York Times, p. A21

Locke, J. (1960). Two Treatises of Government. New York: Mentor

, (1975). An Essay concerning Human Understanding. Oxford: Oxford University Press

Mill, J.S. (1972). Utilitarianism, On Liberty, and Considerations on Representative Government, H.B. Acton (ed.) London: J.M. Dent \& Sons 
, (2002). A System of Logic: Ratiocinative and Inductive. Honolulu: University Press of the Pacific

Mises, L.V. (1996). Human Action (4th rev. ed.) San Francisco: Fox \& Wilkes

Posner, R. (2009). A Failure of Capitalism: The Crisis of '08 and the Descent into Depression. Cambridge: Harvard University Press

Robbins, L. (1932). An Essay on the Nature and Significance of Economic Science. London: Macmillan \& Company

Rothbard, M.N. (2001). Man, Economy, and State. Auburn: Mises Institute

Schwartz, A. (2008, October 18). Bernanke is Fighting the Last War. The Wall Street Journal, p. A11

Selgin, G. (1997). Less than Zero: The Case for a Falling Price Level in a Growing Economy. London: Institute of Economic Affairs

Taylor, J.B. (2009). The Financial Crisis and the Policy Responses: An Empirical Analysis of What Went Wrong. NBER Working Paper, No. W14631

White, L.H. (2008). The Roaring Twenties and Austrian Business Cycle Theory. Retrieved June 12, 2009 from http://econ.as.nyu.edu/docs/IO/9833/White,_Roaring_Twenties_and _ABCT-1.doc

Whitman, J. (2009, March 19). US Fed to Buy $\$ 300 B$ of Debt. National Post, p. A1-2

Willardson, N. (2008, December). Actions to Restore Financial Stability. The Region, 9-17. Retrieved February 16, 2009, from http://www.minneapolisfed.org/pubs/region/08-12/willardson.pdf

Winkelmann, L. \& Winkelmann, R. (1998). Why Are the Unemployed so Unhappy? Evidence from Panel Data. Economica, 65, 1-15

Wolf, M. (2008, December 16). 'Helicopter Ben' Confronts the Challenge of a Lifetime. Financial Times. Retrieved February 16, 2009, from http://www.ft.com/cms/s/0/d049482c-cb8f-11dd-ba02000077b07658.html?nclick_check $=1$ 